\title{
NILAI-NILAI SOSIAL PROFETIK ISLAM DALAM KODE ETIK KOMISI PEMBERANTASAN KORUPSI REPUBLIK INDONESIA
}

\author{
M. Mualif \\ Universitas Pamulang \\ E-mail: doseno1255@unpam.ac.id
}

\author{
Athoillah Islamy \\ Institut Agama Islam Negeri Pekalongan \\ E-mail: athoillahislamy@yahoo.co.id
}

\begin{tabular}{|c|c|c|}
\hline Received & Revised & Accepted \\
\hline 4 July 2021 & 2 Agustus 2021 & 20 September 2021 \\
\hline
\end{tabular}

\section{SOCIAL VALUES OF ISLAMIC PROFETIC BASED ON ETHIC OF CORRUPTION ERRADICATION COMISSION OF INDONESIAN REPUBLIC}

\begin{abstract}
Behind the phenomenon of corruption cases that are still rampant in the Indonesian government, there is an agency that has gained public trust and appreciation, namely the Komisi Pemberantasan Korupsi (KPK). The role and performance of the Corruption Eradication Commission is considered the most successful corruption eradication agency in Indonesia. This study aims to explore and at the same time identify the prophetic social value of Islam in the KPK code of ethics. This qualitative research is in the form of a literature review. This research approach uses a normative-philosophical approach. The primary data source of this research is the code of ethics of the Corruption Eradication Commission (KPK) of the Republic of Indonesia. While the secondary data sources are various scientific researches that are relevant to the main object of the discussion. The analytical theory used is the Ilmu Sosial Profetik paradigm (ISP) which was initiated by Kuntowijoyo. The results of this study conclude the existence of prophetic Islamic social values contained in various values of the KPK code of ethics. First, the value of transcendence (iman) in the code of ethics of religiosity. The existence of the value of religiosity can be said to be a manifestation of the value of Islamic transcendence which makes religious teachings as signs in the activities of social life in the performance of KPK members. Second, the value of humanization in the code of ethics of integrity and professionalism.the values of integrity and professionalism are humanization values that serve as ethical guidelines for KPK members in realizing truth values (amar makruf) in their various duties and activities. Third, the value of liberation (nahi munkar) in the code of ethics for justice and leadership. The KPK code of ethics in the form of justice and
\end{abstract}


leadership values is a fundamental value for KPK members in realizing the orientation of the value of liberation from the political system that has a negative impact on people's lives.

Keywords: Prophetic social, Islam, code of ethics, and erradication corruption.

\section{Abstrak}

Di balik fenomena kasus korupsi yang masih merajalela dalam pemerintahan Indonesia, terdapat sebuah instansi yang mendapatkankepercayaan dan apresiasipublik, yakni Komisi Pemberantasan Korupsi (KPK).Peran dan kinerja KPK dinilai sebagai intansi pemberantas kasuskorupsi paling berhasil di Indonesia.Penelitian ini bertujuan untuk mengeksplorasi sekaligus mengidentifikasi nilai sosial profetik Islam dalam kode etik KPK.Penelitian kualitatif ini berupa kajian pustaka.Pendekatan penelitian ini menggunakan pendekatan normatif-filosofis.Sumber data primer penelitian ini yakni kode etik kode etik politik Komisi Pemberantasan Korupsi (KPK) Republik Indonesia.Sedangkan sumber data sekunder berupa berbagai penelitian ilmiah yang relevan dengan objek inti pembahasan.Teori analisis yang digunakan, yakni teori paradigm Ilmu sosial profetik (ISP) yang digagas oleh Kuntowijoyo.Hasil penelitian ini menyimpulkan keberadaan nilai sosial profetik Islam yang termuat dalam berbagai nilai kode etik KPK.Pertama, nilai transendensi (iman) dalam kode etik religiusitas.Keberadaan nilai religiusitas dapat dikatakan sebagai manifestasi nilai transendensi Islam yang menjadikan ajaran agama sebagai rambu-rambu dalam aktifitas kehidupan sosial dalam kinerja anggota KPK.Kedua, nilai humanisasi dalam kode etik integritas dan profesionalisme.nilai integritas dan profesionalisme merupakan nilai humanisasi yang menjadi pedoman etik bagi anggota KPK dalam mewujudkan nilai-nilai kebenaran (amar makruf) dalam berbagai tugas dan aktifitasnya. Ketiga, nilai liberasi (nahi munkar) dalam kode etik kode etik keadilan dan kepemimpinan. Kode etik KPK yang berupa nilai keadilan dan kepemimpinan menjadi nilai fundamental bagi anggota KPK dalam mewujudkan orientasi nilai liberasi dari sistem politik yang berdampak negatif bagi kehidupan masyarakat.

Kata kunci: sosial profetik, Islam, kode etik, dan pemberantasan korupsi.

\section{Pendahuluan}

Tidak dapat dibantah bahwa kasus tindakan korupsimerusak sistempolitik pemerintahan (negara). ${ }^{1}$ Hal demikian tidak lain disebabkan tindakan korupsi dapat menghambat roda pembangunan suatu negara. ${ }^{2}$ Keberadaan pemerintahan yang dikomandoi oleh pejabat koruptor berpotensi besar mengalami degradasi sosial dan ekonomi yang implikasinya bukan sekedar pada program pembangunan pemerintah, akan tetapi juga pada kehidupan ekonomi rakyat sebagai warga negaranya. ${ }^{3}$

Pada konteks Indonesia, kasus tindakan korupsi telah mengakar kuat dalam sistem pemerintahan. ${ }^{4}$ Dampak dari tindakan korupsi yang terjadi sangat komplek bagi tatan kehidupan pemerintah maupun masyarakat sipil di Indonesia. ${ }^{5}$ Oleh

${ }^{1}$ Ida Bagus Ketut Weda, "Korupsi Dalam Patologi Sosial: Sebab, Akibat Dan Penanganannya Untuk Pembangunan Di Indonesia," Jurnal Advokasi 3, no. 2 (2013): 119.

${ }^{2}$ Irfan Setiawan, S. IP, and M. Si, "Mengikis Perilaku Korupsi Pada Birokrasi Pemerintahan," Jurnal Ilmu Pemerintahan Widya Praja 42 (2016): 33-34.

${ }^{3}$ Latipah Latipah, "Korupsi Di Parlemen," ADALAH 1, no. 1 (2018): 3.

${ }^{4}$ Ismail, "Fungsi Penyidik Kpk Dalam Pemberantasan Tindak Pidana Korupsi Berdasarkan Undang-Undang Nomor 30 Tahun 2002" (PhD Thesis, Tadulako University, n.d.), 3.

${ }^{5}$ Victor K. Pesik, "Kewenangan KPK Dalam Pemberantasan Tindak Pidana Korupsi," LEX ET SOCIETATIS 2, no. 6 (2014): 105-6. 
sebab itu, tidaklah mengehrankan jika negara Indonesia senantiasamenduduki posisisepuluh besar sebagai negara dengan angka kasus tindak korupsi terbesar didunia. ${ }^{6}$ Kondisi demikian sudah pastinya menimbulkan dilema dan keprihatian besar di tengah masyarakat. Tidak hanya itu, besarnya kasus tindak korupsi juga menjadi problem sekaligus tantangan tersendiri bagi pemerintah Indonesia untuk memberantasnya.$^{7}$

Merespons tingginya angka kasus tindakan korupsi di Indonesia, pada tanggal 20 Desember 2003 lahirlah Komisi Pemberantasan Korupsi (KPK) Republik Indonesia yang dibentuk berdasarkan atas Undang-Undang Nomor 30 tahun 2002 tentang Komisi Pemberantasan Tindak Pidana Korupsi dengan orientasi untuk menanggulangi pelbagai tindakan korupsi di Indonesia. ${ }^{8}$

Tingginya tingkat kepercayaan dan apresiasi publik terhadap KPK tidak dapat dilepaskan dari prestasi kinerja KPK selama ini. Penting diketahui bahwa KPK telah dinilai sebagai intansi pemberantas tindak korupsi paling berhasil di Indonesia. Penilaian demikian tidaklah berlebihan, mengingat belum ada satu pun putusan incracht yang membebaskan terdakwa kasus korupsi. Maka dari itu, tidak mengherankan jika pada tahun 2013, KPK mendapat penghargaan Ramon Magsaysay Award dalam hal penegakan hukum. Penghargaan tersebut secara tidak langsung menunjukan bahwa kinerja KPK diapresiasi oleh masyarakat dunia. Bahkan selama 4 tahun terakhir ini, eksistensi KPK juga telah berhasil mengungkap skandal kasus tindakan korupsi yang di dalamnya melibatkan para elite politik, seperti proses penetapan tersangka atas perkara penerbitan Surat Keterangan Lunas Bantuan Likuiditas Bank Indonesia yang merugikan keuangan negara sebesar Rp 4,58 triliun. Begitu juga pada kasus korupsi atas pengadaan E-KTP yang melibatkan banyak politisi. ${ }^{9}$

Prestasi kinerja KPK yang baik sebagaimana di atas tidak terlepas dari pelbagai nilai kode etik yang menjadi basis pradigmatik KPK dalam menjalankan tugas kerja sosial dalam memberantas pelbagai tindakan korupsi. Di mana pelbagai nilai kode etik KPK tersebut seyogyanya juga menjadi prinsip kinerja oleh seluruh lapisan pejabat pemerintah (politisi) yang mengemban amanah dari masyarakat. ${ }^{10}$ Meningat kendatipun telah ada naskah kode etik yang menjadi pedoman politisi dan partai politik. ${ }^{11}$ Namun realitas memperlihatkan kasus tindakan korupsi para politisi masih banyak ditemukan. Pernyataan demikian dapat dibuktikan dari data yang ada bahwa sejak keberadaan KPKdibentuk sampai pada tahun 2019, terdapat sekitar 107

\footnotetext{
${ }^{6}$ Muhammad Abdul Kholiq, "Eksistensi KPK Dalam Peradiian Korupsi Di Indonesia,” Jurnal Hukum IUS QUIA IUSTUM 11, no. 26 (2004): 30-31.

${ }^{7}$ Supeni Anggraeni Mapuasari and Hadi Mahmudah, "Korupsi Berjamaah: Konsensus Sosial Atas Gratifikasi Dan Suap," Integritas: Jurnal Antikorupsi 4, no. 2 (2018): 160.

${ }^{8}$ Pesik, "Kewenangan KPK Dalam Pemberantasan Tindak Pidana Korupsi," 106.

${ }^{9}$ Kurnia Ramadhana, "Menyoal Kinerja KPK: Antara Harapan Dan Pencapaian," Integritas: Jurnal Antikorupsi 5, no. 2 (2019): 152-53.

${ }^{10}$ Syamsuddin Haris et al., Naskah Kode Etik Politisi Dan Partai Politik (Jakarta: Direktorat Pendidikan dan Pelayanan Masyarakat Kedeputian Pencegahan, Komisi Pemberantasan Korupsi Bekerja sama dengan Pusat Penelitian Politik, Lembaga Ilmu Pengetahuan Indonesia, 2016), V.

${ }^{11}$ Athoillah Islamy, "Paradigma Sosial Profetik Dalam Kode Etik Politik Di Indonesia," $A S Y$ SYAR'IYYAH: JURNAL ILMU SYARI'AH DAN PERBANKAN ISLAM 5, no. 2 (2020): 158.
} 
Kepala Daerah teridentifikasi korupsi. Tidak berhenti di situ, selama periode 20142019 tercatat 23 anggota DPR RI aktif terjerat korupsi. ${ }^{12}$

Berpijak dari kegelisahan akademik di atas, penelitian ini bermaksud untuk mengungkap pelbagai nilai sosial profetik dalam ajaran Islam yang termuat dalam kode etik KPK. Upaya tersebut penting dilakukan agar dapat menyadarkan kembali bahwa pelbagainilai kode etik KPK memiliki relevansi dengan nilai sosial profetikajaran Islam. Di mana diharapkan dapat menyadarkan kembali para anggota KPK maupun pejabat politik pada umumnya atas pentingnya menjadikan kote etik politik KPKsebagai pedoman dalam melaksankan peran dan tugasnya, terlebih bagi pejabat yang muslim khusunya, dan non muslim pada umumnya.

Penulis sadar bahwa terdapat beberapa kajian yang memiliki relevansi dengan objek inti pembahasan penelitian ini, antara lain Achmad Badjuri (2011) dalam penelitian berjudul "Peranan Komisi Pemberantasan Korupsi (Kpk) Sebagai Lembaga AntiKorupsi Di Indonesia."Penelitian tersebut menyatakan bahwa instansi KPK memilikinilai strategis sekaligus politis bagi kemaslahatan sistem pemerintahan. Oleh sebab itu, eksistensi KPKdengan dukungan masyarakat diharapkan dapat memberantassegala tindakan kasus korupsi yang ada. ${ }^{13}$ Kemudian Victor K Pesik (2014) dalam penelitian berjudul"Kewenangan Kpk Dalam Pemberantasan Tindak Pidana Korupsi."Penelitian tersebut menyatakan KPK memiliki kewenangansupervisi pada lembaga penyidik Kepolisian dan penyidik Kejaksaan.terkait penyidikan dan penuntutan kasus pidana korupsi. Eksistensi otoritas supervise yang dimiliki KPK tersebut dimaksudkan agar dapatmeminimalisir terjadinya penyalahgunaan otoritas oleh penyidik polisi dan jaksa dalam pemberantasan kasus pidana korupsi. Mengingat otoritas supervisi KPK dibutuhkan agara dapat mewujudkan prinsip kecermatan, kehati-hatian, sehingga diharapkan tidak terjadi tumpang tindih antar ketiga instansi tersebut saat menjalankan wewenangnya masing-masing. ${ }^{14}$

Berikutnya, penelitian Abdul Azis (2018) dengan judul "Kewenangan Komisi Pemberantasan Korupsi Dalam Pemberantasan Tindak Pidana Korupsi Berdasarkan Teori NegaraHukum."Penelitian tersebut menyatakan bahwa regulasi terkait wewenang KPK harus dapat mengikuti kebutuhan hukum negara, yakni harusmemuat kesetaraan Hak Azasi Manusia (HAM). ${ }^{15}$ Selanjutnya, Kartika S. Wahyuningrum, Hari S. Disemadi Dan Nyoman S. Putra Jaya (2020) dengan judul “Independensi Komisi Pemberantasan Korupsi: Benarkah Ada?"Hasil penelitian tersebut menunjukan telah terjadi pelemahan instansi KPK yang dapat dilihat dengan dibentuknya Dewan Pengawas. Tidak hanya itu, juga dapat dinilai dari adanya kualifikasi anggota KPK yang harus berasal dari Aparatur Sipil Negara

\footnotetext{
${ }^{12}$ Donal Fariz, "Pemerintahan Joko Widodo Dan Serangan Politik Terhadap KPK," Integritas: Jurnal Antikorupsi 5, no. 2 (2019): 23.

${ }^{13}$ Achmad Badjuri, "Peranan Komisi Pemberantasan Korupsi (KPK) Sebagai Lembaga Anti Korupsi Di Indonesia," Jurnal Bisnis Dan Ekonomi 18, no. 1 (2011): 91-92.

${ }^{14}$ Pesik, "Kewenangan KPK Dalam Pemberantasan Tindak Pidana Korupsi," 111.

${ }^{15}$ Abdul Azis, "Kewenangan Komisi Pemberantasan Korupsi Dalam Pemberantasan Tindak Pidana Korupsi Berdasarkan Teori Negara Hukum," Jurnal Surya Kencana Satu: Dinamika Masalah Hukum Dan Keadilan 9, no. 2 (2019): 88.
} 
(ASN). Hal tersebut berimplikasi pada terikatnya dengan komando pusat yang membatasi ruang gerak KPK. ${ }^{16}$

Berdasarkan berbagai penelitian terdahulu di atas, dapat dikatakan bahwa belum ditemukan penelitian yang fokus mengeksplorasi sekaligus mengidentifikasi pelbagai nilai sosial profetik dalam kode etik KPK. Poin lacuna inilah yang kemudiandapat menjadi distingsi penelitian ini dari berbagai penelitain sebelumnya

\section{Metode Penelitian}

Jenis penelitian ini masuk kategori penelitian kualitatif yang berupastudi pustaka (library research) ${ }^{17}$ Sementara itu, pendekatanpenelitian yang digunakan, yaknipendekatan normatif-filosofis. Objek data utama penelitian ini, yakni pelbagai nilai kode etik politik Komisi Pemberantasan Korupsi (KPK) Republik Indonesia.Teori analisis yang digunakan yakni teori ilmu sosial profetik yang digagas Kuntowijoyo meliputi nilai transendensi, humanisasi, dan liberasi. Ketiga nilai tersebut akan dijadikan sebagai teori analisis dalam mengeksplorasi sekaligus mengidentifikasi pelbagai nilai sosial profetik yang termuat dalam kode etik KPK.Adapun sifat pendekatan penelitian, yakni deskriptif-analitik.

\section{Hasil dan Pembahasan \\ Paradigma Ilmu Sosial Profetik}

Diskursus seputar perdebatan tentang relasi antara ilmu-ilmu sosial Barat sekuler dan ilmu-ilmu sosial Islam telah menginspirasi Kutowijoyo untuk mengajukan konsep ilmu sosial Islam yang disebutnya dengan Ilmu Sosial Propetik (ISP).Melalui ide ISP, Kuntowijoyo berharap dapat menjembatani gap antara eksistensi ilmu sosial sekuler dan ilmu sosial Islam. ${ }^{18}$ Oleh sebab itulah, ide ISP menekankan pentingnya keberadaan ilmu-ilmu sosial memiliki landasan sebagai pijakan dasar untuk mencapai tujuan yang diinginkan.Atas dasar ini, ide ISP merumuskan tiga nilai dasar dalam konstruksi paradigmatiknya, yakni nilai humanisasi (amar makruf), nilai liberasi (nahimunkar), dan transendensi (iman). Ketiga nilai tersebut sejatinya digali dari tiga nilai ajaran Islam yang termuat dalam Qur'an surat Ali Imran ayat 110. ${ }^{9}$ Penjelasan lebih lanjut tentang tiga nilai tersebut akan diuraikan di bawah ini.

\footnotetext{
${ }^{16}$ Kartika Sasi Wahyuningrum, Hari Sutra Disemadi, and Nyoman Serikat Putra Jaya, "Independensi Komisi Pemberantasan Korupsi: Benarkah Ada?," Refleksi Hukum: Jurnal Ilmu Hukum 4, no. 2 (2020): 239.

${ }^{17}$ Penelitian kualitatif merupakan penelitian yang bertujuan untuk menganalisa objek penelitian secara holistik, deskriptif tanpa metode analisis statistik. Lexy J. Moleong, "Metodologi Penelitian Kualitatif Edisi Revisi," Bandung: PT Remaja Rosdakarya 103 (2007): 6.

${ }^{18}$ Athoillah Islamy and Nurul Istiani, "Aktualisasi Nilai-Nilai Profetik Dalam Pendidikan Keluarga Di Tengah Pandemi Covid-19," Mawa'izh: Jurnal Dakwah Dan Pengembangan Sosial Kemanusiaan 11, no. 2 (2020): 177.

${ }^{19 H u s n u l ~ M u t t a q i n, ~ " M e n u j u ~ S o s i o l o g i ~ P r o f e t i k, " ~ J u r n a l ~ S o s i o l o g i ~ R e f l e k t i f ~ 10, ~ n o . ~} 1$ (2016): 221-22.
} 
Pertama, nilai humanisasi.Landasan nilai humanisasi (humanisme)ini bersumber dari ajaran Islam berupa amar makruf. ${ }^{20}$ Terkait makna term makruf, Abdul Karim Sheikh menjelaskan bahwa kata "makruf” memiliki makna yang luas, antara lain kebajikan, kebenaran, keadilan, dan pengabdian. ${ }^{21}$ Melalui nilai humanism ini, Kuntwijoyo berusaha menyadarkan manusia agar lebih mempertimbangkan eksistensi perintah Tuhandalamsegala arah kepentingan hidup manusia.Dengan kata lain, peradaban manusia tidak hanya dipandang pada tataran rasional, melainkan juga menekankan nilai-nilai transendental yang bersumber dari ajaran agama (Islam). ${ }^{22}$

Kedua, nilai liberasi.Keberadaan nilai liberasi dalam ide ISP merupakan nilai yang bersumber dari pemaknaan atas ajaran Islam yang berupanahi munkar. ${ }^{23} \mathrm{Abdul}$ Karim Sheikh juga menyatakan bahwa term munkar tidak hanya berarti perilaku yang dilarang oleh ajaran Islam, tetapi juga merujuk pada berbagai perilaku yang melanggar akal sehat dan peradaban budaya manusia.. ${ }^{24}$ Nilai liberasi ini memiliki empat orientasi yang diusung.Pertama, untuk membebaskan umat manusia dari sistem ilmu pengetahuan yang materialistis dan membedakan kelas sosial dan diskriminasi gender.Kedua, untuk membebaskan sistem sosial dari pengaruh buruk industri dan sistem sosial.Ketiga, untuk membebaskan sistem ekonomi yang berdampak negatif pada kehidupan manusia.Keempat, untuk membebaskan sistem politik dari sistem politik yang buruk dan jahat seperti rezim otoriter dan kediktatoran. ${ }^{25}$ Jika dilihat dari keempat tujuan di atast, maka ide dasar dari nilai humanisasi memiliki titik temu dengan aliran pemikiran sosialis Barat yang berbeda seperti Marxisme, Komunisme.Hanya saja yang membedakan, yakni keberadaan nilai liberasi berpusat pada berbagai nilai transenden dalam ajaran Islam. ${ }^{26}$

Ketiga, nilai transendensi.Dasar nilai liberasi dalam ide ISP berpijak pada ajaran Islam berupa keimanan (iman). ${ }^{27}$ Oleh karena itu, nilai transendensi pada hakikatnya merupakan landasan utama dari nilai dua paradigma sosial profetik humanisasi dan liberasi.Dalam bahasa lain, nilai- humanisasi, liberasi dan transendensi merupakan tiga nilai utama dari paradigma ISP yang terintegrasi dan sinergis sebagai landasan ke-Islaman dalam kehidupan sosial. ${ }^{28}$

20Ibid., 225.

${ }^{21}$ Abdul Karim Syeikh, "Rekonstruksi Makna Dan Metode Penerapan Amar Ma'ruf Nahi Munkar Berdasarkan Al-Qur'an," Al-Idarah: Jurnal Manajemen Dan Administrasi Islam 2, no. 2 (2018): 19.

22Muttaqin, “Menuju Sosiologi Profetik," 226.

23Ibid.

${ }^{24}$ Syeikh, "Rekonstruksi Makna Dan Metode Penerapan Amar Ma'ruf Nahi Munkar Berdasarkan Al-Qur'an," 19.

${ }^{25}$ M. Zainal Abidin, Paradigma Islam Dalam Pembangunan Ilmu Integralistik: Membaca Pemikiran Kuntowijoyo (IAIN Antasari Press, 2016), 157.

26Islamy, "Paradigma Sosial Profetik Dalam Kode Etik Politik Di Indonesia," 166-67.

27Muttaqin, "Menuju Sosiologi Profetik," 227-28.

${ }^{28}$ Maskur Maskur, "Ilmu Sosial Profetik Kuntowijoyo (Telaah Atas Relasi Humanisasi, Liberasi Dan Transendensi)" (PhD Thesis, Universitas Islam Negeri Alauddin Makassar, 2012), 127. 
Dalam penelitian ini, tiga nilaiISP di atas akan digunakan sebagai teori analisis dalam mengeksplorasi dan mengidentifikasi berbagai nilai sosial profetik Islam yang termuat dalam pelbagai kode etik Komisi Pemberantasan Korupsi (KP) yang menjadi objek inti pembahasan dalam penelitian ini.

\section{Tiga Pilar Nilai Sosial Profetik Islam dalam Kode EtikKomisi Pemberantasan Korupsi (KPK)}

Gagasan upaya menjadikan nilai-nilai profetik dalam Ilmu Politik bukan sekedar untuk menolak klaim bebas nilai dalam paradigmapositivism, melainkan lebih jauh dari itu, yakni meniscayakan keberadaan ilmu politik agar memiliki landasan nilai sebagai pijakan dalam mencapai tujuan yang dikehendakinya. Oleh sebab itu, Ilmu Politik Profetik tidak cukup berhenti pada upaya untuk menjelaskan dan memahami realitas secara apa adanya, akan tetapi lebih jauh dari itu, yakniupaya untuk mentransformasikan nilai-nilai profetik menuju cita-cita yang didambakan oleh kehidupansosial masyarakat. ${ }^{29}$

Pada konteks nilai profetik ajaran Islam sejatinya tidak dapat dilepaskan dari nilai-nilai universal yang melekat dalam ajaran Islam itu sendiri.Nurcholish madjid atau yang akrab disapa Cak Nur, menuturkan bahwa universalisme ajaran Islam seyogyanya memiliki implikasi luas pada ragam ajaran Islam yang ada. ${ }^{30}$ Dalam subpembahasan ini akan diuraikan analisa eksplorasi sekligus identifikasiberbagai nilai sosial profetik yang termuat dalam kode etik Komisi Pemberantasan Korupsi (KPK). Kode etik tersebut mengacu padanaskah dokumen Peraturan Komisi Pemberantasan Korupsi Republik Indonesia Nomor 7 Tahun 2013 Tentang Nilai-Nilai Dasar Pribadi, Kode Etik, dan Pedoman Prilaku Komisi Pemebrantasan Korupsi. Pada naskah dokumen tersebut disebutkan terdapat berbgainilai kode etik anggota KPK dalam menjalankan peran dan tugasnya, antara lain, sebagai berikut.

\section{Nilai Transendensi dalam Kode Etik Religiusitas}

Tidak dipungkiri bahwa aspek religiusitasmerupakan wujud manifestasi bukti keyakinan,keberagamaan atau wujud spritualitas seseorangdariajaran agama atau kepercayaan yang diyakininya.Dalam kode etik KPK, pelbagai unsur religiusitas meliputi sikap ketakwaan yang menyakini bahwa setiap tindakan seorang hamba dalam bekerja dalam pengawasan Tuhan.Unsur religisiutas tersebut diharapkan dapat melahirkan berbagai sikap atau etos dalam bekerja, seperti ketulusan keikhlasan, saling menghormati dan kesantunan dalam mewujudkan terciptanaya kondisi pekerjaan yang kondisif.

Kode etik KPK dalam bentuk nilai religiusitas menunjukan bahwaajaran agama harus menjadi pijakan etisbagi anggota komisi ketika menjalankan tugas pekerjaan dalam pemberantasan kasus korupsi yang ada. ${ }^{3}$ Dalam perspektif Ilmu

${ }^{29}$ Muhammad Nur, "Rekontruksi Epistemologi Politik: Dari Humanistik Ke Profetik," AsySyir'ah: Jurnal Ilmu Syari'ah Dan Hukum 48, no. 1 (2014): 152-53.

${ }^{30}$ Athoillah Islamy, "Pemikiran Hukum Islam Nurcholish Madjid" (Disertasi Pascasarjana Universitas Islam Negeri Walisongo, 2021), 115.

${ }^{31}$ Athoillah Islamy, "Gender Mainstreaming Dalam Al-Qur'an Dan Hadis Serta Relevansinya Terhadap Epistemologi Hukum Islam,” Jurnal Hukum Islam 15, no. 1 (2017): 182. 
Sosial Profetik (ISP) dapat dikatakan bahwa pentingya menjadikan ajaran agama sebagai landasan etis maupun etik dalam bekerja merupakanwujud transendensi dalam membumikan nilai-nilai sosial profetik ajaran Islam di tengah kehidupan sosial masyarakat. ${ }^{32}$ Tidak berhenti di sisni, penting disadari kembali bahwa dalam paradigma ISP, keberadaan nilai transendensi menjadi komitmen keimanan seorang muslim dalam kehidupan sosialnya. ${ }^{33}$ Dari sini dapat dikatakan bahwa kode etik KPK dalam bentuk nilai religiusitas merupakan wujud nilai transendensi bagi para anggota komisi dalam tugas pekerjaaanya.

Pentingnya nilai religiusitas sebagai bagian dari kode etik KPK merupakan hal yang niscaya dan realistis. Mengingat terdapatrelasi positif antara spirit religiusitasdengan intense tindakan anti korupsi. Di mana tingkat religiusitas seseorang yang semakin tinggi, maka semakin tinggi juga tingkat intensi anti korupsi dalam dirinya. ${ }^{34}$ Oleh sebab itu, tidaklah berlebihan jika nilai transendensi dalam konstruksi kode etik KPK yang berupa unsur religiusitasmengisyaratkan pentingnya sikap konsistensi keberagamaan dalam konteks kehidupan sosial.Di mana dalam perspektif ISP, dinyatakan spirit nilai transendensi dapat direalisasikan ketika nilai ajaran al-Qur'an dan Hadis sebagai dasar ajaran Islam dapat dijadikan sebagai landasan etik dalam kehidupan sosial.Dalam hal ini, jika ditinjau dalam perpektif psikologi Islam, juga dinyatakan bahwa Islam merupakan ajaran agama yang memuat pelbagai sumber nilaibagi kehidupan pengikutnya dalam pembentukan kondisi psikis dan juga perilaku. ${ }^{35}$ Dengan demikian kode etik KPK yang berupa nilai religiusitasdapat dikatakan sebagai manifestasi nilai transendensi Islam yang menjadi ajaran agama sebagai rambu-rambu dalam aktifitas kehidupan sosial dalam kinerja anggota KPK.

\section{Nilai Humanisasi dalam Kode Etik Integritas dan Profesionalisme}

Integritas dalam perspektif kode etik KPK merupakan kesatuan antara pola pikir, perasaan, ucapan yang selaras dengan hari nurani, dan norma yang berlaku di komisi.Pelbagai unsur dalam kode etik integritas ini, antara lain, taat pada peraturan dan perundang-undangan, konsisten pada nilai kebenaran, kejujuran, tidak berlaku koruptif, amanah, dan reputasi baik.Sementara itu, kode etik KPK yang berupa profesionalisme merupakan bentuk kompetensi untuk melakukan tugas dan fungsi secara benar sehingga dibutuhkan adanya kemampuan dan keahlian serta ketrampilan dalam bidang yang ditekuninya agar hasil kerjayan berdampak pada efektifitas terhadap pemberantasan tindak korupsi.Pelbagai unsur profesionalisme dalam kode etik KPK tersebut meliputi kompetensi dan selalu meningkatkannya,

\footnotetext{
${ }^{32}$ Maskur, "Ilmu Sosial Profetik Kuntowijoyo (Telaah Atas Relasi Humanisasi, Liberasi Dan Transendensi)," 127.

${ }^{33}$ Muttaqin, "Menuju Sosiologi Profetik," 227-28.

${ }^{34}$ Humaira Mumtazah, Agus Abdul Rahman, and Sarbini Sarbini, "Religiusitas Dan Intensi Anti Korupsi: Peran Moderasi Kebersyukuran," Journal An-Nafs: Kajian Penelitian Psikologi 5, no. 1 (2020): 111.

${ }^{35}$ Athoillah Islamy, "Dialectic Motivation, Behavior And Spiritual Peak Experience In The Perspective Of Islamic Psychology,” Alfuad: Jurnal Sosial Keagamaan 3, no. 2 (2019): 38.
} 
bekerja sesuai aturan yang ada, objektif, independen, terukur, bekerja keras, produktif dan inovatif.

Manifestasi nilai integritas dan profesionalisme dalam aktifitas pekerjaan merupakan hal yang berkaitan erat. Hal demikian disebabkan nilai integritasakanmendorong seseorang untuk mengarahkan fungsi atau tugas partikularitasnya dalam mewujdukantujuan kebaikan bersama. Dalam konteks kode etik KPK, nilai integritas tersebutbukan sekedar terwujud secara empiris dalam mencegah tindakan korupsi, melainkan logis dengan menggunakan pendekatan integrative berupa sistem, substansi, struktur hukum dan moral(etika). ${ }^{36}$ Oleh sebab itu, kode etik KPK yang berupa nilai integritas dan profesionalisme paralel dengan prinsip etos kerja dalam perspektif Islam.Di antara etoskerja dalam ajaran Islam, antara lain, nilai khaira ummah, al-adalah, musyawarah, ulul albab, etos imamah, etos tauhid yang membebaskan. ${ }^{37}$ Sementara itu, jikaditinjau dalam perspektif Ilmu Sosial Profetik (ISP), keberadaan nilai integritas dan profesionalisme dalam kode etik KPK dapat dikatakan sebagai upaya mewujudkan nilai-nilai humanisasi dalam kinerja KPK. Di mana penting kita ketahui kembali bahwa nilai humanisasi dalam perspktif ISP merupakan merupakan salah nilai ajaran sosial profetik yang mengacu pada ajaran Islam berupa amar ma'ruf (menegakkan kebenaran). ${ }^{38}$ Pada ide humanisme Islam tersebut, Kuntowijoyo berupaya untuk mengembalikan kesadaran manusia agar dapatmemiliki orientasi demi terwujudnya kemaslahatan sosial bagi kehidupan manusia dengan tanpa mengabaikan pijakan nilai-nilai teologis.Berpijak pada kesadaran tersebut, maka, baik buruknyaperadaban manusia tidak sekedar mengacu pada tolak ukur rasionalitas manusia, melainkan juga berpijak pada pelbagai nilai yang bersumber dari ajaran teologis. ${ }^{39}$ Atas dasar inilah, maka tidaklah berlebihan jika kode etik berupa nilai integritas dan profesionalisme merupakan nilai humanisasi yang menjadi pedoman etik bagi anggota KPK dalam mewujudkan nilai-nilai kebenaran (amar makruf) dalam berbagai tugas dan aktifitasnya.

\section{Nilai Liberasi dalam Kode Etik Keadilan dan Kepemimpinan}

Dalam kode etik KPK, nilai keadilan dimaknai sebagai pemberian bentuk perlakuan dan kesempatan yang sama keapada setiap orang.Oleh sebab itu, berbabagai unsur nilai keadilan dalam kode etik KPKmeliputi penghormatan terhadap asas kepastian hukum, praduga tak bersalah, kesetaraan di depan hukum. Sementara itu, kode etik KPK berupa nilai kepemimpinan merupakan bentuk kompetensi untuk mengerakan dan mempengaruhi dalam mencapai tujuan bersama serta berani mengambil keputusan yang dapat dipertanggung jawabkan.Pelbagai unsur nilai kepemimpinan dalam kode etik KPK tersebut

${ }^{36}$ G. Gufroni, "Integritas Moral Dan Korelasinya Dengan Perilaku Korupsi” (Prosiding Seminar Nasional \& Call for Papers Hukum Transendental, 2018), 425.

${ }^{37}$ Mohammad Irham, "Etos Kerja Dan Korelasinya Dengan Peluang Dan Tantangan Profesionalitas Masyarakat Muslim Di Era Modern," Substantia: Jurnal Ilmu-Ilmu Ushuluddin 14, no. 2 (2012): 21-22.

${ }^{38}$ Muttaqin, "Menuju Sosiologi Profetik," 225.

${ }^{39}$ Ibid., 226. 
memiliki tujuan pada pelayanan, kesetaraan, keteladanan, kepeloporan, penggerak perubahan, dan bimbingan, dalam mencapai tujuan komisi.

Keberadaan nilai keadilan dan kepemimpinan sebagai bagian dari kode etik KPK parallel dengan spirit kepemimpinan profetik.Dalam konteks ajaran Islam, nilai kepemimpinan profetik tersebut setidaknya dapat mengacu pada nilai-nilai kenabian yang meliputi empat aspek, yaitu sidiq (jujur), amanah (akuntabilitas), tabligh (komunikatif efektif)), dan fathonah (intelktualis)..$^{40}$ Berbagai nilai kepemimpinan profetik tersebut dapat mengantarkan anggota KPKuntuk tidak mengutamakan kepentingan individu pribadi di atas lembaga komisi dalam menjalankan tugas.Tidak hanya itu, Kebradaan kode etik KPK berupa nilai keadilan dan kepemimpinan menicayakan bahwa keberadaan KPK sebagai institusi publik dituntut agar dapat berorientasi pada kepentingan dan kemaslahatan universal bagi kehidupan sosial masyarakat.Oleh sebab itu, segala aktifitas kerja KPK harus memiliki orientasi dalam mewujudkankemaslahatan publik.Spirit nilai kemaslahatan publik dalam kode etik KPK yang berupa nilai keadilan dankepemimpinan tersebut sejalannilai liberasidalam perspektif Ilmu Sosial Profetik (ISP).Penting diketahui bahwa liberasi merupakan nilai sosial profetik yang mengacu pada nilai ajaran Islam yang berupa nahi munkar. ${ }^{41} \mathrm{Di}$ mana dalam konteks kehidupan sistem politik pemerintahan, nilai liberasi memiliki orientasi untuk membebaskan manusia dari belenggu sistem politik yang berdampak negatif bagi kehidupan masyarakat seperti, sistem politik otoriter, diktator, korup, dan lain sebagainya. ${ }^{42}$ Atas dasar inilah, kode etik KPK yang berupa nilai keadilan dan kepemimpinan menjadi nilai esensial bagi anggota KPK dalam mewujudkan orientasi dari nilai liberasi dalam konteks sistem politik pemerintahan.

\section{Simpulan}

Berpijak pada hasilpembahasanpenelitian inidapat disimpulkan berbagai nilai kode etik Komisi Pemberantasan Korupsi (KPK) memiliki titik temu dengan nilai sosial profetik Islam.Kesimpulan ini dapat dilihat darikeberadaan nilai sosial profetik Islam yang termuat dalam berbagai nilai kode etik KPK.Pertama, nilai transendensi dalam kode etik religiusitas.Keberadaan nilai religiusitas (iman) dapat dikatakan sebagai manifestasi nilai transendensi Islam yang menjadikan ajaran agama sebagai rambu-rambu dalam aktifitas kehidupan sosial dalam kinerja anggota KPK.Kedua, nilai humanisasi dalam kode etik integritas dan profesionalisme.nilai integritas dan profesionalisme merupakan nilai humanisasi yang menjadi pedoman etik bagi anggota KPK dalam mewujudkan nilai-nilai kebenaran (amar makruf) dalam berbagai tugas dan aktifitasnya.Ketiga, nilai liberasi (nahi munkar) dalam kode etik kode etik keadilan dan kepemimpinan. Kode etik KPK yang berupa nilai keadilan dan kepemimpinan menjadi nilai fundamental bagi anggota KPK dalam

\footnotetext{
${ }^{40}$ Sus Budiharto, "Peran Kepemimpinan Profetik Dalam Kepemimpinan Nasional," in Conference on Islamic Psychology (The 1st National, Yogyakarta: Inter-Islamic Conference on Psychology, 2015), 6-7.

${ }^{41}$ Muttaqin, "Menuju Sosiologi Profetik," 226.

${ }^{42}$ Abidin, Paradigma Islam Dalam Pembangunan Ilmu Integralistik, 157.
} 
mewujudkan orientasi nilai liberasi dari sistem politik yang berdampak negatif bagi kehidupan masyarakat.

Dengan ditemukannya muatan nilai sosial profetik Islam dalam kode etik KPK, maka temuan penelitian ini dapat menunjukan bahwa kendatipun secara nomatif tekstual keberadaan berbagai kode etik KPK tidak menunjukan nilai-nilai ajaran Islam.Namun sejatinya berbagai kode etik KPK tersebut memiliki titik temu dengan nilai-nilai sosial profetik dalam ajaran Islam. Kesimpulan demikian seyogyanya dapat menjadi counter bagi kalangan masyarakat Indonesia yang masih menilai berbagai regulasi atau norma dalam system politik pemerintahan Indonesia bertentangan dengan spirit ajaran Islam.

\section{DAFTAR PUSTAKA}

Abidin, M. Zainal.Paradigma Islam Dalam Pembangunan Ilmu Integralistik: Membaca Pemikiran Kuntowijoyo. IAIN Antasari Press, 2016.

Azis, Abdul. "Kewenangan Komisi Pemberantasan Korupsi Dalam Pemberantasan Tindak Pidana Korupsi Berdasarkan Teori Negara Hukum.” Jurnal Surya Kencana Satu: Dinamika Masalah Hukum Dan Keadilan 9, no. 2 (2019).

Badjuri, Achmad. "Peranan Komisi Pemberantasan Korupsi (KPK) Sebagai Lembaga Anti Korupsi Di Indonesia.”Jurnal Bisnis Dan Ekonomi 18, no. 1 (2011).

Budiharto, Sus. “Peran Kepemimpinan Profetik Dalam Kepemimpinan Nasional.”In Conference on Islamic Psychology. Yogyakarta: Inter-Islamic Conference on Psychology, 2015.

Fariz, Donal. "Pemerintahan Joko Widodo Dan Serangan Politik Terhadap KPK." Integritas: Jurnal Antikorupsi 5, no. 2 (2019).

Gufroni, G. “Integritas Moral Dan Korelasinya Dengan Perilaku Korupsi.” Prosiding Seminar Nasional \& Call for Papers Hukum Transendental, 2018.

Haris, Syamsuddin, Ikrar Nusa Bhakti, Moch Nurhasim, Sri Nuryanti, Sri Yanuarti, Mardiyanto Wahyu Tryatmoko, Irene H. Gayatri, Indriana Kartini, Sarah Nuraini Siregar, and Aisah Putri Biduatri. Naskah Kode Etik Politisi Dan Partai Politik. Jakarta: Direktorat Pendidikan dan Pelayanan Masyarakat Kedeputian Pencegahan, Komisi Pemberantasan Korupsi Bekerja sama dengan Pusat Penelitian Politik, Lembaga Ilmu Pengetahuan Indonesia, 2016.

Irham, Mohammad. "Etos Kerja Dan Korelasinya Dengan Peluang Dan Tantangan Profesionalitas Masyarakat Muslim Di Era Modern."Substantia: Jurnal IlmuIlmu Ushuluddin 14, no. 2 (2012).

Islamy, Athoillah. "Dialectic Motivation, Behavior And Spiritual Peak Experience In The Perspective Of Islamic Psychology.” Alfuad: Jurnal Sosial Keagamaan 3, no. 2 (2019).

-_- "Gender Mainstreaming Dalam Al-Qur'an Dan Hadis Serta Relevansinya Terhadap Epistemologi Hukum Islam.”Jurnal Hukum Islam 15, no. 1 (2017).

"Paradigma Sosial Profetik Dalam Kode Etik Politik Di Indonesia." ASY SYAR'IYYAH: JURNAL ILMU SYARI'AH DAN PERBANKAN ISLAM 5, no. 2 (2020). 
———. "Pemikiran Hukum Islam Nurcholish Madjid." Disertasi Pascasarjana Universitas Islam Negeri Walisongo, 2021.

Islamy, Athoillah, and Nurul Istiani."Aktualisasi Nilai-Nilai Profetik Dalam Pendidikan Keluarga Di Tengah Pandemi Covid-19."Mawa'izh: Jurnal Dakwah Dan Pengembangan Sosial Kemanusiaan 11, no. 2 (2020).

Ismail. "Fungsi Penyidik Kpk Dalam Pemberantasan Tindak Pidana Korupsi Berdasarkan Undang-Undang Nomor 30 Tahun 2002." PhD Thesis, Tadulako University, n.d.

Kholiq, Muhammad Abdul. "Eksistensi KPK Dalam Peradiian Korupsi Di Indonesia."Jurnal Hukum IUS QUIA IUSTUM 11, no. 26 (2004).

Latipah, Latipah. "Korupsi Di Parlemen.” ADALAH 1, no. 1 (2018).

Mapuasari, Supeni Anggraeni, and Hadi Mahmudah. "Korupsi Berjamaah: Konsensus Sosial Atas Gratifikasi Dan Suap.” Integritas: Jurnal Antikorupsi 4, no. 2 (2018).

Maskur, Maskur. "Ilmu Sosial Profetik Kuntowijoyo (Telaah Atas Relasi Humanisasi, Liberasi Dan Transendensi).” PhD Thesis, Universitas Islam Negeri Alauddin Makassar, 2012.

Moleong, Lexy J. "Metodologi Penelitian Kualitatif Edisi Revisi."Bandung: PT Remaja Rosdakarya 103 (2007).

Mumtazah, Humaira, Agus Abdul Rahman, and Sarbini Sarbini. "Religiusitas Dan Intensi Anti Korupsi: Peran Moderasi Kebersyukuran.” Journal An-Nafs: Kajian Penelitian Psikologi 5, no. 1 (2020).

Muttaqin, Husnul. “Menuju Sosiologi Profetik.” Jurnal Sosiologi Reflektif 10, no. 1 (2016).

Nur, Muhammad. "Rekontruksi Epistemologi Politik: Dari Humanistik Ke Profetik." Asy-Syir'ah: Jurnal Ilmu Syari’ah Dan Hukum 48, no. 1 (2014).

Pesik, Victor K. "Kewenangan KPK Dalam Pemberantasan Tindak Pidana Korupsi." LEX ET SOCIETATIS 2, no. 6 (2014).

Ramadhana, Kurnia. "Menyoal Kinerja KPK: Antara Harapan Dan Pencapaian.” Integritas: Jurnal Antikorupsi 5, no. 2 (2019).

Setiawan, Irfan, S. IP, and M. Si. "Mengikis Perilaku Korupsi Pada Birokrasi Pemerintahan." Jurnal Ilmu Pemerintahan Widya Praja 42 (2016).

Syeikh, Abdul Karim. "Rekonstruksi Makna Dan Metode Penerapan Amar Ma'ruf Nahi Munkar Berdasarkan Al-Qur'an."Al-Idarah: Jurnal Manajemen Dan Administrasi Islam 2, no. 2 (2018).

Wahyuningrum, Kartika Sasi, Hari Sutra Disemadi, and Nyoman Serikat Putra Jaya. "Independensi Komisi Pemberantasan Korupsi: Benarkah Ada?" Refleksi Hukum: Jurnal Ilmu Hukum 4, no. 2 (2020).

Weda, Ida Bagus Ketut. "Korupsi Dalam Patologi Sosial: Sebab, Akibat Dan Penanganannya Untuk Pembangunan Di Indonesia." Jurnal Advokasi 3, no. 2 (2013). 